11.01.2018

\title{
Accounting for Government Grants: Standard-Setting and Accounting Choice
}

\author{
Christian Stadler ${ }^{\mathrm{a}, *}$ and Christopher W. Nobes ${ }^{\mathrm{b}}$
}

${ }^{a}$ Department of Accounting and Finance, Lancaster University Management School Lancaster, Lancashire, LA1 4YX, UK

c.stadler@lancaster.ac.uk

${ }^{b}$ School of Management, Royal Holloway, University of London

Egham, Surrey, TW20 0EX, UK

and

Business School, University of Sydney

chris.nobes@rhul.ac.uk

* Corresponding author

The authors are grateful for comments from Mary Barth, Christopher Napier, Ann Tarca and two reviewers of this journal. They also acknowledge research assistance from Rebecca Warren, and technical advice from Irina Lukicheva and Chungwoo Suh. 


\title{
Accounting for Government Grants: Standard-Setting and Accounting Choice
}

\author{
Abstract: \\ This paper provides evidence on several matters relating to accounting for government \\ grants under International Financial Reporting Standards (IFRS). Focusing on grants related \\ to assets, we trace the development of International Accounting Standard (IAS) 20, outline \\ some of the problems of current accounting practice, and suggest why these have not \\ been addressed by the standard-setter. Then, by hand-collecting data relating to 559 firms \\ from 15 countries, we empirically analyze several issues. We show that asset grants are \\ economically important for some firms and that the frequency of grants is significantly \\ different across the countries. For the non-financial firms in our sample, we identify the \\ grant-related accounting policy choice: a firm can either show the grant as deferred \\ income or net it against the asset. The options are roughly equally popular overall but the \\ firm's country of domicile is strongly associated with the choice. Further, as a key element \\ of disclosure quality for this topic, we investigate whether or not the balance sheet- \\ related numbers relating to grants are disclosed, finding that many firms do not disclose \\ them. Disclosure quality is better for firms which use the 'deferred income' option, and it \\ is also better in countries where a higher proportion of firms has received government \\ grants. International differences and poor disclosure are detrimental to international \\ comparisons, so we conclude that the policy choice should be removed from the \\ accounting standard.
}

Keywords: government grants, IAS 20, accounting choice, international differences

JEL descriptors: M41 


\section{Introduction}

Accounting for government grants has become a neglected area of standard-setting and it is little researched. Several standards of the International Accounting Standards Board (IASB) deal with the issue (e.g. separately for listed firms and for unlisted firms), but they have quite different requirements, some involving choice by preparers. Further, the issue is important in the context of the political pressure on standard-setters to increase transparency about financial flows between firms and governments (e.g. OECD, 2015). However, there is no coverage of this area (which could be called 'non-reciprocal transfers') in the conceptual framework of the IASB (2010a) which is designed to guide standard-setting. Further, there are no proposals to undertake research or to amend the framework or standards in the area. Unusually for any accounting topic, there are no requirements in US generally accepted accounting principles (GAAP). Although the IASB has not resolved the issue, for reasons discussed in this paper, other influential parties have acknowledged its importance (EFRAG, 2016). ${ }^{1}$ This paper analyzes accounting for asset grants both conceptually and empirically.

International Accounting Standard 20 (IAS 20, Accounting for Government Grants and Disclosure of Government Assistance) deals with how to account for various types of government assistance. The general principle is old-fashioned matching: a grant should be recognized as income when the costs (which the grant is intended to compensate) are

1 The European Financial Reporting Advisory Group has launched a 'proactive' research project, though not yet produced any papers. 
recognized as expenses (para. 12). Thus, a grant intended to compensate running costs is recognized as income in line with the costs. Similarly, a grant related to the purchase of an asset is taken to income over the life of the asset. This means that there will be a credit balance equal to the excess of cash received or receivable over the amount so far treated as income. IAS 20 allows two options for the presentation of this credit on the balance sheet: show it as deferred income (a sort of liability) or net it against the asset (para. 24). Consequently, the choice affects leverage, because the 'deferred income' option results in larger liabilities. ${ }^{2}$ In the income statement, a government grant increases profit over several years by the same amounts under both options, either by increasing 'other operating income' or by reducing the depreciation expense.

Our empirical analysis of 559 firms from 15 countries shows that, in 2013, 43\% of non-financial firms have asset grants, peaking at $89 \%$ of firms in Germany. These grants are economically important for some firms. For example, the Spanish firm, Enagas, reported government grants for the purchase of infrastructure assets ${ }^{3}$ with a carrying amount of $€ 253$ million, which represented $11.9 \%$ of its shareholders' equity. ${ }^{4}$ Further, if Enagas had financed the respective assets internally instead of receiving grants, its profit

2 Investors and analysts could adjust for this if there is sufficient disclosure, but we show that there is not sufficient disclosure for many firms.

3 The reported government grants for assets of Enagas relate to investments in regasification plants, gas transport infrastructure and underground storage facilities, and were received from EU structural funds, Spanish regional authorities and the Spanish state (Annual Report 2013, p. 298).

4 Calculation (all in thousands of euros, except percentages): 253,234/2,118,427=11.9\% (Annual Report 2013, pp. 246+295). 
would have been $3.4 \%$ lower because of higher depreciation. ${ }^{5}$ The importance of grants also varies internationally. At its peak, in Italy, grants amount on average to over $14 \%$ of equity for firms with grants.

In this paper, we analyze the international differences in the accounting requirements in this policy area. We outline the theoretical issues concerning the accounting treatment of government grants. We show how different countries arrived at different solutions. We trace the development of the topic in international standards, which has led to different answers in three IASB documents: IAS 20, IAS 41 (Agriculture) and the International Financial Reporting Standard for Small and Medium-sized Entities (IFRS for SMES). We examine why the standard-setters have no formal plans to address these conflicts or to otherwise update the oldest unrevised international standard. ${ }^{6}$ Our approach involves analyzing other related conceptual problems faced by the IASB, such as the extent to which financial reporting should reflect a pure asset/liability view (Sprouse, 1978).

We then empirically analyze two aspects of accounting choice regarding government grants for assets: the policy choice for the balance sheet treatment; and whether or not a firm discloses the corresponding number, i.e. the balance of deferred income or the amount by which the asset is reduced. Since IAS 20 is an old standard, it contains

5 Calculation (all in thousands of euros, except percentages): [19,028*(1-28.45\%)]/404,256=3.4\% (Annual Report 2013, pp. 245+294). We have assumed that the depreciation has an effect on tax, and have calculated the tax rate using the information in the income statement: $160,749 / 565,005=28.45 \%$.

6 IAS 20 has not been revised since its issue in 1983, apart from a re-formatting in 1994. All earlier IASs (and most of the later ones) have been withdrawn or revised since 1983. 
rudimentary disclosure requirements: it merely requires disclosure of the accounting policy, 'the nature and extent of government grants', and any unfulfilled conditions (para. 39). We investigate whether this vague phrasing leads to varied or inadequate information.

Our empirical analysis is based on hand-collected data relating to 559 firms, though we mostly examine a sub-sample of 421 non-financial firms. Regarding policy choice, the options are roughly equally popular in our sample overall, but we find highly significant international differences in choice. The data supports a hypothesis which we develop that a firm's IFRS policy choice is influenced by prior or current national regulations. To the extent that data on pre-IFRS practices is available, there is even clearer support for a proposition (not statistically tested) that a particular firm continues with its pre-IFRS policy. There is no evidence in the regulations, in the literature or in firms' reports that the differing accounting treatments relate to different economic features of asset grants. Regarding disclosure quality, many firms do not disclose the balance sheet-related numbers on grants. We hypothesize and find that disclosure quality, as measured on this basis, is better for firms which use the 'deferred income' option and better in countries where a higher proportion of firms has received government grants. International accounting differences (if unrelated to underlying economic differences) and poor disclosure are detrimental to international comparisons. We conclude that the policy choice should be removed from the accounting standard. 
Our specific contributions are as follows. First, we are not aware of any previous analysis of international differences in accounting regulations on grants which includes reference to IASB documents or which was carried out after widespread adoption of IFRS. Also, firms' policy choices on grants are not investigated by most of the prior papers on IFRS policy choice (e.g. Kvaal and Nobes, 2010; Nobes and Stadler, 2013). Ours is the first comprehensive empirical study on this topic. Furthermore, disclosures on this topic have not been researched before. Our findings of poor disclosure are important because, without disclosure, an investor or analyst is unable to adjust balance sheets so that they are all on the same basis. We find highly significant international differences in these areas.

The paper proceeds as follows. In Section 2, we outline the technical problem and the responses of standard-setters. In Section 3, we review empirical research on IFRS policy choice. In Section 4, we develop our hypotheses. Section 5 explains our sample and data. The next two sections contain our empirical analyses: Section 6 on policy choice, and Section 7 on disclosure quality. Section 8 is a brief discussion of the economic importance of asset grants to our sample of firms. In Section 9, we record our conclusions and policy recommendations. 


\section{The technical problem and the responses of regulators}

\subsection{Rule-making on asset grants}

The theory of how to treat asset grants was investigated by the group of standardsetters called 'The G4+1' which operated in the 1990 s (Street, 2005). The G4+1 included the standard-setters of Australia, Canada, New Zealand, ${ }^{7}$ the UK and the USA, plus the International Accounting Standards Committee (IASC). Its report on grants by Westwood and Mackenzie (1999) recommended (see p. 23) that unconditional grants should be recognized immediately in full as assets (e.g. cash) and as income. They derived this answer from the conceptual frameworks of the standard-setters: ${ }^{8}$ because such a grant does not give rise to a liability (as there is no present obligation for an expected outflow of resources), the credit must be income. In this context, 'unconditional' refers to the absence of stipulations such as that the asset must not be sold or moved to another location within a certain period. ${ }^{9}$ The $\mathrm{G} 4+1$ report was unable to arrive at a definite conclusion on how to account for grants which do have conditions (Westwood and Mackenzie, 1999, pp. 32-38).

IAS 20 pre-dates and is inconsistent with the IASB's framework ${ }^{10}$ and the G4+1's conclusion. Instead, the sources of IAS 20 are the national GAAPs of the countries which

7 The New Zealand standard-setter had not originally been a member, and the group's name was never adjusted for its arrival.

8 Including FASB (1980 and 1985) and IASC (1989).

9 Westwood and Mackenzie (1999, p. 26) distinguish between such conditions and 'restrictions' which direct the use of assets. Those authors do not consider that the existence of restrictions affects their conclusion that grants are immediate income.

10 Either as initially issued by the IASC (1989) or as amended by the IASB (2010). 
were members of the Board of the IASC ${ }^{11}$ when IAS 20 was issued in 1982. In US GAAP, there were no requirements on government grants, perhaps because grants are not common in the US; but practice has been to use one of the two choices now found in IAS 20 (Ernst \& Young, 2005, p. 581). The accountancy bodies of Europe's three largest economies (France, Germany and the UK) were also members of the IASC. However, the EU's Fourth Directive on company law (of 1978) did not discuss government grants, and there is no line in its balance sheet formats for them. ${ }^{12}$ This gap is probably explained by the absence of German requirements on the issue (Ordelheide and Pfaff, 1994, p. 149), given that German law was the model for the first draft of the Directive (Nobes, 1983). In France, the plan comptable général had an account in which to store the credit balance of deferred income from an asset grant. ${ }^{13}$ The most obvious source of IAS $20^{\prime}$ 's content was the UK's standard, SSAP 4 (Accounting for Government Grants), which had been issued in 1974. It required an asset grant to be recognized as income over the life of the asset (para. 15), and allowed a choice for the postponed credit: either showing the grant as deferred income or deducting the grant from the asset. ${ }^{14}$ When the IASC addressed this issue it concluded, without much controversy (Camfferman and Zeff, 2007, p. 135), that entities should be allowed to choose between these two treatments, which can still be found in the current version of IAS 20 (see para. 24).

\footnotetext{
11 Australia, Canada, France, (West) Germany, Japan, Mexico, Nigeria, The Netherlands, South Africa, the UK (and Ireland) and the USA.

12 The same still applies in the revised Directive of 2013.

13 131: Subventions d'équipement, as part of Subventions d'investissement.

14 SSAP 4 was amended in 1990, as discussed later. It was UK GAAP until the end of 2014.
} 
When the IASC was drafting IAS 41 (Agriculture, issued in 2001) a major technical problem with grants became clear: given that IAS 41 requires biological assets to be measured at a version of fair value, ${ }^{15}$ how could it make sense to show an asset at a current market value minus a historical grant? This problem led the IASC to adopt the treatment proposed by the $\mathrm{G} 4+1$ for unconditional grants: immediate recognition as income (IAS 41, para. 34). In IFRS this only applies, so far, to grants related to biological assets. In our investigations, we discovered that other assets are sometimes held at fair value minus a grant. ${ }^{16}$

The IASB at one time had provisionally decided to amend IAS 20 by adopting the 'income' approach of IAS 41 (IASB, 2004, p. 5), but did not proceed for reasons discussed in the next section. When preparing the IFRS for SMEs (issued in 2009), the IASB did adopt this conceptually modern and simple treatment (para. 24.4). This was too radical for the UK's new GAAP which, although based on the IFRS for SMEs, allows a choice between treating the grant as income or as deferred income (FRS 102, para. 24.4).

\subsection{Why does the issue remain unresolved?}

Despite the existence of different answers in various IASB documents, the issue of government grants is not on the IASB's agenda, and it was not mentioned in the agenda consultation of 2015 (IASB, 2015a). Further, the matter of non-reciprocal transfers had not

\footnotetext{
15 Fair value less costs to sell (IAS 41, para. 12).

16 See the 2014 annual report of the Australian firm, CFS Retail Property Trust (p. 107).
} 
been included in the IASC's original framework of 1989, neither is it in the 2010 revision, nor in the exposure draft of 2015.

We now ask why the matter is not currently receiving attention from the IASB. The context is that the treatment of government grants is related to major unresolved controversies, in particular: (i) the extent to which financial reporting reflects a pure asset/liability view rather than involving matching of costs with incomes, and (ii) the measurement and recognition of contingencies. The first issue was controversial in the discussions that preceded the development of the conceptual framework of the Financial Accounting Standards Board (FASB) (Zeff, 2016a, pp. 245-8). Although the published framework, and others which derive from it (such as the IASB's), give supremacy to the definitions of asset and liability, ${ }^{17}$ there is a continuing tension in accounting practice between that approach and matching. For example, until the FASB's and IASB's new standards on revenue of 2014 come into force, the percentage of completion method is used for many construction contracts. ${ }^{18}$ This method matches income with costs, irrespective of when the constructed asset passes from the constructor to the customer. Even under the new standards, the tension is clear. For example, commissions paid to salesmen before any work on a project begins are stored in the balance sheet as assets to

\footnotetext{
17 See, for example, FASB, 1980, para.s 19-33; FASB, 1985, para.s 25-40; IASC, 1989, para. 49; and IASB, 2010a, para. 4.4.

18 See, for example, IAS 11, para. 22.
} 
be matched against future costs, even though they do not meet the definition of asset because they are not a resource controlled by the entity. ${ }^{19}$

An example of the same tension in the case of liabilities is that unvested 'obligations' resulting from defined benefit pensions or cash-settled share-based payments are recorded as liabilities under US GAAP or IFRS even though the firm could avoid the outflows by sacking the staff. ${ }^{20}$ This practice does not fit the definition of liability but it does fit the idea of matching. The IASB is clearly aware of this major problem (IASB, 2013, para.s $3.39-3.97)$.

The second major unresolved topic is contingencies. The connection with government grants is that many grants are conditional, suggesting that immediate recognition should be partly balanced by recognizing obligations. However, the present version of IAS 37 (Provisions, Contingent Liabilities and Contingent Assets) requires recognition of obligations only when outflows are probable (para. 14). A project to revise IAS 37, so that probability would be an aspect of measurement instead of a constraint on recognition, led to two exposure drafts: in 2005 and 2010 (Morley, 2016, p. 226). The IASB had decided to wait for developments on IAS 37 before revising IAS 20 (IASB, 2010b). However, the proposals to change IAS 37 were very unpopular ${ }^{21}$ and were abandoned in

19 See IFRS 15 (para. 91) and ASC 340-40-25-1.

20 See IAS 19 (para. 51) and IFRS 2 (para. 32); and ASC 715-30-35 and 718-10-33.

21 For example, see: http://www.iasplus.com/en/publications/global/project-insights/liabilities (accessed 01.02.16). 
2010.22 As with the asset/liability issue above, a major problem elsewhere has contributed to delaying, apparently indefinitely, a solution to the problems of accounting for government grants.

A topic related to government grants is emissions trading schemes, which involve the receipt of rights from governments. On this topic, the IASB issued in 2004 an 'Interpretation' (IFRIC 3) of its standards, including IAS 20 and IAS 37. This led to such controversy in the EU, partly about matching expenses and income, that the Interpretation had to be withdrawn (see EFRAG, 2005). This was a scarring experience for the IASB, and the topic is still unresolved (IASB, 2015b). It further illustrates the controversial nature of the area.

We suggest that the IASB has been deterred from revising IAS 20 because of this context. In particular, neither of the options in the standard is consistent with the conceptual framework, but the conceptually obvious answer (that an unconditional grant is income) offends the deeply-ingrained idea of matching. There is also the problem of how to deal with conditions, which imply the need for some form of spreading, as discussed in IAS 20 (e.g. para.s 15 (b), 18 and 19).

As mentioned earlier, the FASB has a simpler way out: there is no US GAAP on the issue. When the FASB's predecessor tried to solve the similar topic of investment tax

22 See: http://www.ifrs.org/Current-Projects/IASB-Projects/Liabilities/Pages/Liabilities.aspx (accessed 04.02.16), and http://www.ifrs.org/Current-Projects/IASB-Projects/IASB-agenda-consultation/2015agenda-consultation/Documents/Request\%20for\%20Views Agenda\%20Consultation AUG\%202015.pdf (para. A15, accessed 04.02.16). 
credits, there was a political crisis and the standard-setters abandoned the project (Zeff, 2016b, p. 273). This particular topic is specifically scoped out of both IAS 20 (see para. 2) and IAS 12 (Income Taxes, see para. 4). Therefore, firms reporting under IFRS in receipt of such credits need to create a policy, by analogy with one of those two standards. ${ }^{23}$ We do not analyze this choice in our empirical investigation.

\section{Empirical research on IFRS options}

Nobes (2006) set out a list of topics on which there were 'overt options' in IFRS, such as the choice between the cost basis and fair value for measuring property, plant and equipment (PPE). For 16 of these topics, Kvaal and Nobes (2010 and 2012) investigated policy choice by firms. They found a highly significant association between policy choice and a firm's domicile. This they explain largely in terms of inertia of practice: pre-IFRS practices were conditioned by national regulations and other national incentives such as tax, and firms continued pre-IFRS practices where IFRS options allowed. The association with country survives the inclusion of other firm-related factors, such as size, sector or leverage (Stadler and Nobes, 2014).

Although government grants was in the list of topics in Nobes (2006), it was not empirically examined in the above papers, nor was it included as an attribute of accounting practice used to classify firms by country in the studies of Nobes (2011) and Nobes and Stadler (2013). This ignoring of the topic has been followed by others (e.g.

23 This is done under the guidance of IAS 8 (Accounting Policies, Changes in Accounting Estimates and Errors, para. 10). See, for example, the 2014 annual report of Saputo, p. 41. 
Lourenço et al., 2015). Kvaal and Nobes (2010) do not explain why government grants was not included in their empirical study. The omission was of limited importance for their 2005 data because 16 topics were studied. Of these, seven were measurement topics which might be considered more important than presentation issues. However, the IASB has gradually been removing overt options, such that recent studies (e.g. Lourenço et al., 2015) consider only two measurement topics. It has, therefore, become more of a problem that government grants have been ignored by researchers. Although the choice is referred to as a matter of presentation in IAS 20 (and, indeed, it does not affect income or net assets), it could also be considered to relate to measurement because it affects the size of liabilities and thus the leverage ratio.

Haller and Wehrfritz (2013, Table 6) do include government grants in their study of overt options, but they only consider two countries: Germany and the UK. They find a significant difference between the countries, with German firms using the netting method (deduction against asset) much more than UK firms, which conforms to the general hypothesis of preserving pre-IFRS practice, given that the netting method was deemed to be illegal under UK GAAP (see Section 4.2). In the survey of KPMG and von Keitz (2006), government grants is one of the 26 topics covered (p. 12), but in contrast to many other topics, not much detailed information is provided. The only concrete country-level statistic is that $86 \%$ of Spanish firms use the netting method and, as will be explained in Section 6.1, this may be misleading data. 


\section{Outline of empirical analysis, and development of hypotheses}

\subsection{Outline of empirical analysis, and countries chosen for investigation}

In Sections 6 and 7, we empirically analyze two aspects of accounting for government grants related to assets: the policy choice regarding the balance sheet (deferred income or netting against asset), and whether or not there is disclosure of the corresponding number (i.e. the balance of deferred income or the amount by which the asset is reduced).

For our analyses, we include firms from the following 15 countries/jurisdictions (hereafter 'countries'): Australia (AU), ${ }^{24}$ Brazil (BR), Canada (CA), Switzerland (CH), China (CN), Germany (DE), Spain (ES), France (FR), United Kingdom (GB), Hong Kong (HK), Italy (IT), Japan (JP), South Korea (KR), Russia (RU), and South Africa (ZA). These are the home countries of the largest stock markets that either mandatorily implemented IFRS or (in the cases of China, Japan and Switzerland) had many large firms using IFRS voluntarily. ${ }^{25}$

\subsection{Hypothesis on policy choice}

We expect that, in common with all other topics previously investigated in the literature, IFRS policy choice on grants will be strongly associated with firms' pre-IFRS practices, which tend to be maintained where possible under IFRS. This means that a firm's domicile is a strong predictor of policy choice, because a firm's pre-IFRS practices

${ }^{24}$ Country abbreviations are according to the ISO 3166-1 alpha-2 code.

25 In our sample year, 2013, listed firms in Switzerland and Japan were allowed to use IFRS. The Chinese firms were listed on the Hong Kong Stock Exchange (HKEx), which required IFRS from 2005 to 2009. Since 2010, the HKEx accepts Chinese GAAP financial statements, but most firms in our sample have continued to use IFRS. 
were influenced by various country-related factors, particularly pre-IFRS regulations. However, it is now very difficult to study pre-IFRS practices for a full sample of IFRS reporters for various reasons, including that (i) some large listed firms did not exist or were not listed before IFRS adoption, and (ii) disclosure of policy notes was sparse in some countries before IFRS. Therefore, we would be willing to use pre-IFRS survey data as a proxy for pre-IFRS practices. Unfortunately, we are only able to locate data on pre-IFRS practices on this topic for one country (Germany), apart from old data or descriptions (FEE, 1991, pp. 289-293; AAF, 1991, pp. 19-21). We use the data on Germany below, but for our other countries, we use information on pre-IFRS national requirements. These are good proxies for pre-IFRS practice when they contain clear instructions that mandate one of the treatments which comprise the options in IAS 20.

Although pre-IFRS practice (and therefore country association) is a strong explanation of IFRS policy choice, there is variation within some countries, so other factors must be involved (Stadler and Nobes, 2014). The 'deferred income' choice makes leverage look worse although, as we will discuss, investors and analysts could adjust for this for some firms. We include leverage as a control when we test hypotheses in Sections 6 and 7. Since the policy choice does not affect income, it seems unlikely that either earnings management or tax effects are relevant. Costs of disclosure (administrative and proprietary) seem unlikely to be much different under the two options, though we discuss ease of disclosure in Section 4.3. 
We now briefly outline the backgrounds to the choice of the IAS 20 option in each of our 15 countries. We start with those in which we expect the 'deferred income' option to be preferred. As explained in Section 2.1, a choice between 'deferred income' and 'netting' had been allowed in the UK by the original version of SSAP 4. However, the Standard was amended in 1990 and pointed out that, for firms set up as companies, ${ }^{26}$ the second treatment had probably been illegal since the Companies Act 1981 (which implemented the EU Fourth Directive into UK law) because it would mean that the asset would not be recorded at cost. ${ }^{27}$ In France, the 'deferred income' approach was ${ }^{28}$ also required in the period immediately before IFRS was adopted. The plan comptable général has a special heading 'investment grants' as item 13 in its list of credit balances remaining at the end of a year. On the balance sheet, this is shown in an ambiguous position: after share capital and reserves but still included as part of 'capitaux propres' rather than with provisions and creditors (Gélard, 2001, p. 1088). Similarly, in Brazil, the pre-IFRS law required an asset grant to be recorded as a balance inside equity, and then taken to income in line with the depreciation of the asset. ${ }^{29}$ Under the Spanish accounting plan, asset grants were required to be shown as deferred income (Gonzalo and Gallizo, 1992, p. 141; Diaz and Torre, 2001, p. 2245). In Italy, the law was silent; but the accounting

26 In order to be listed, a firm must be registered as a 'public limited company' (PLC). Not all PLCs are listed. PLCs are outnumbered greatly by private limited companies. Further, many firms are not companies, but partnerships or sole traders.

27 SSAP 4, para. 34. See, also, AAF (1991, p. 15). At the time of the amendment, the relevant part of the law was the Companies Act 1985, Sch. 4, para.s 17 and 26.

28 In many cases, such as France, Italy and Spain, the national requirements still are as outlined here, but we concentrate on the position immediately before IFRS adoption.

29 Law 6.404/76; see CFC (2006, p. 29). 
standard specifically allowed both treatments, recommending the deferred income one (Zambon, 1998, p. 626). Earlier practice was to credit equity immediately (FEE, 1991, p.293; AAF, 1991, p. 20; Loli and Wilcke, 2001, p. 1629). This suggests a likely bias against deduction from assets. As will be explained in Section 6.3, we confirm this by examining pre-IFRS practices. Under Russian GAAP, assets should be shown gross, i.e. the deferred income approach is required. ${ }^{30}$

Other national regulatory issues are more important than pre-IFRS requirements in two of our countries. Australia had the only pre-IFRS national GAAP which was consistent with the G4+1's 'immediate income' recommendation. This was written after IAS $20 .{ }^{31}$ However, in this case even pre-IFRS regulation is outweighed by the fact that the Australian version of IAS 20 (i.e. AASB 120) applicable in the first two years of IFRS adoption (2005-6) had deleted the netting option, so Australian IFRS practice set out on a 'deferred income' track. In the case of China, our sample firms prepare both IFRS reports and Chinese GAAP reports. Chinese GAAP is loosely based on IFRS but the Chinese version of IAS 20 (i.e. ASBE 16) had no netting option in our sample year,'32 so the 'deferred

30 Russian Standard PBU 13/2000. We are grateful for advice from Irina Lukicheva of PwC.

31 This instruction was in AASB 1004. Rather confusingly, the term used in Australian GAAP for IFRS 'income' was 'revenue', and vice versa (see AASB, 2002, p. 49). The Australian Accounting Standards Board was founded in 1991.

32 Our sample year is 2013 (see below). ASBE 16 was revised in 2017 and the netting option was added (EY, 2017). 
income' practice was used under Chinese GAAP and was likely to be copied over into a Chinese firm's IFRS statements. ${ }^{33}$

Thus, of our 15 countries, the above eight require, required or recommended the 'deferred income' treatment under national GAAP. ${ }^{34}$ We conclude that, under IAS 20, this option is more likely to be chosen in these countries than in the other countries discussed below. This enables us to form a hypothesis relating to the eight countries (Australia, Brazil, China, France, Italy, Russia, Spain, and the UK):

H1: Under IFRS, the deferred income treatment for government grants is more common in countries where it is or was required or recommended under national GAAP.

The pre-IFRS requirements in the other countries were as follows. South Korea is the only one of our countries in which there was a requirement to use the netting approach (KAS No. 5, para. 18). ${ }^{35}$ Under German national rules, the same two choices as in IAS 20 were found (Ordelheide and Pfaff, 1994, p. 149; Ballwieser, 2001, p. 1300). ${ }^{36}$ For Germany uniquely, we have useful data on pre-IFRS practices: Haller and Wehrfritz (2013, p. 44)

33 Under ASBE 16, there is an exception: if the grant documentation requires the firm to show the grant as a capital reserve, then it must do so. However, this exception does not involve netting.

${ }^{34}$ As part of this, we include the initial Australian version of IFRS.

${ }^{35}$ We are grateful for advice on this from Chungwoo Suh (IASB) and Sang-Eun Park (Samil, PwC).

${ }^{36}$ Ordelheide and Pfaff (but not Ballwieser) mention that the netting method was 'preferred' in a statement of 1984 which was designed to guide auditors. However, this is outranked by the empirical evidence in the following sentence. 
report that practice was fairly evenly split between the two choices. ${ }^{37}$ Hong Kong and South Africa had accounting standards based on the UK's SSAP 4 (i.e. the choice of treatments) without the EU-inspired legal problem which apparently removed the netting option. In Canada, the same two choices were also allowed. ${ }^{38}$

Switzerland and Japan are special cases in that IFRS is a choice, and one (unlike the position for Chinese companies) which is unencumbered by the need to prepare local GAAP consolidated statements for other purposes. Nevertheless, local GAAP and its influence on national practices might affect IFRS choices. Swiss GAAP (FER) did not cover the issue (Bertschinger, 2001). In Japan, there has been a different choice from that allowed by IAS 20: between (i) netting against the asset, and (ii) initially recording the grant as a reserve in equity, and then gradually taking this into retained earnings ( $\mathrm{PwC}$, 2013, p. 18). Thus, for Japanese firms, 'deferred income' was a newly available option when adopting IFRS, though one somewhat similar to (ii). A further complication is that some Japanese firms were using US GAAP before adopting IFRS, so had no requirements on this issue. Section 8 examines for some countries (including Japan) whether there is evidence in favour of the more precise hypothesis that each individual firm's IFRS policy choice tends to follow its pre-IFRS practice.

${ }^{37}$ This data relates to 2001 annual reports, and shows $56.25 \%$ of firms showing deferred income and $42.75 \%$ using netting.

${ }^{38}$ See p. 19 of: http://www.iasplus.com/en/binary/ca/0807canadaifrssummary.pdf (accessed January, 5, 2017). 


\subsection{Hypotheses on disclosure quality}

As mentioned earlier, IAS 20 (para. 39 (b)) requires a firm to disclose the nature and extent of government grants recognised in the financial statements'. A more general objective of IFRS statements is comparability (IASB, 2010a, para. QC 20). In the context of optional policies, this requires a firm to disclose sufficient information to allow users to adjust financial statements from one option to the other. So, for either option, a user needs to know the effect on the balance sheet; that is, either the balance of deferred income or the reduction in assets. In terms of ease of disclosure, we suggest that it is much simpler for a firm to disclose a balance of deferred income than to include grants (and the annual change in them due to depreciation) in the already complex table relating to PPE (or to disclose it in the text surrounding the PPE table). For the reasons given in this paragraph, we therefore expect:

H2: Disclosure of the effect of grants on balance sheets is better for firms choosing the 'deferred income' option.

Previous research suggests that firms learn from others about how to improve reporting and that analysts push firms to copy improvements (e.g. Meek et al., 1995; Botosan and Harris, 2000; Kvaal and Nobes, 2012). Given that IFRS policy choice is much more determined by country than by industry (see Stadler and Nobes, 2014), any diffusion seems most likely to occur within a country. Thus, we expect that disclosure on any 
particular accounting topic is better if the topic is common in a country so that a firm has many comparators. This leads to:

H3: Disclosure about grants is better in countries in which a higher proportion of firms has received government grants.

\section{Sample and data for empirical analyses}

Our choice of countries was explained in Section 4.1. Our sample comprises the constituents of the major stock market indices of these countries, ${ }^{39}$ which gives an initial sample of 813 firms. We then eliminate 98 firms with foreign influence, ${ }^{40} 31$ subsidiaries of listed domestic firms, and 35 firms which do not use IFRS. We also eliminate 74 firms for which we do not have data for our sample year, 2013 (see below). ${ }^{41}$ Finally, we eliminate 14 firms for which the data on asset grants are unclear ${ }^{42}$ and 2 firms where the grant is said to be immaterial. This reduces our sample to 559 firms. Table 1 gives the

39 S\&P/ASX-50 (Australia), IBrX-50 (Brazil), S\&P/TSX-60 (Canada), SMI (Switzerland), Hang Seng China Enterprises Index (China), DAX-30 \& 10 largest (by market capitalization) constituents of MDAX-50 (Germany), IBEX-35 (Spain), CAC-40 (France), FTSE-100 (United Kingdom), Hang Seng (Hong Kong), FTSE/MIB-40 (Italy), KOSPI-50 (South Korea), RTS-50 (Russia), and FTSE/JSE Top 40 (South Africa). For countries which started using IFRS from 2005 (or earlier), we use the constituents on 31 December 2005 or 31 December 2010 or both; for countries which started using IFRS after 2005 (Canada, Russia and South Korea), we use the constituents on 31 December 2010; for Brazil, we use the constituents on 30 June 2012. For Japan, we use those firms which had chosen to use IFRS by 2013.

40 Firms with foreign influence comprise the following: foreign firms (e.g. Telecom New Zealand in Australia), subsidiaries of listed foreign firms (e.g. TUI Travel in the UK because it is a subsidiary of the German TUI), firms listed in Hong Kong's Hang Seng index that have a Chinese ultimate parent (e.g. China Mobile) and firms with other foreign influence (e.g. BHP Billiton because it has a dual-listed structure, with listings in both Australia and the UK).

41 This mainly applies if a firm is included in the initial sample but has been delisted by 2013 (e.g. following a takeover).

42 Specifically, we exclude firms with any of the following characteristics: it is unclear whether the firm has asset grants; the policy choice is unclear; the firm says that it does not provide disclosure because it is government controlled (Aeroflot); or both policy options are used (which only applies to two firms). 
detail of this sample selection. Table 2 shows the country and industry distribution. Industry is according to the first digit of the Industry Classification Benchmark (ICB) code.

[insert Tables 1 and 2 about here]

In our analyses, we use one observation per firm because our data (both policy choice and disclosure quality) are sticky over time. ${ }^{43}$ We use 2013/14 (hereafter '2013') as our sample year, i.e. we use data for accounting periods ending on 31 December 2013 or earliest thereafter. All data related to government grants are hand-collected ${ }^{44}$ from firms' annual reports and the remaining data are from Worldscope. ${ }^{45}$ Many firms do not use the term 'government grants' but use such terms as: investment grants, capital grants, construction grants, official grants, government subsidies, subsidies, investment subsidies, capital subsidies, government assistance and government incentives. We include these cases where it is clear that government grants for assets are involved. The policy choice is generally disclosed in the policy notes. However, for each firm, we check whether the policy note is in line with the respective number in other notes (if the number is

43 IAS 8 generally requires consistent policy choice over time (para.s 14(b) and 15) and requires disclosures about any changes (para. 29).

44 When a firm uses a presentation currency that is different from its home currency (i.e. the currency of its domicile), we convert the reported number into home currency using Worldscope's exchange rate for translating the balance sheet (WC18214), because Worldscope reports all data of a firm in its home currency.

45 For Japan Tobacco, we find its policy choice in the annual report for the accounting period ending on 31 March 2014. However, Worldscope does not contain corresponding data because Japan Tobacco changed its accounting year, and the 2014 numbers in Worldscope relate to the accounting period ending on 31 December 2014. We therefore hand-collect the required accounting data from the firm's annual report and obtain data on market capitalization from Thomson Reuters Eikon. In order to ensure that our handcollected data (on total shareholders' equity and total debt) are consistent with the Worldscope data of other firms, we check Worldscope's numbers for Japan Tobacco for the accounting year ending on 31 March 2013 and then collect the corresponding numbers for 31 March 2014. 
disclosed). We identify two firms (DSME and OCI of South Korea) that have incorrect policy notes, in that they report use of the 'deferred income' policy but the PPE notes show that the grants are netted from the assets.

Table 3 includes data on the frequency of grants. Overall, 33\% (185 out of 559) of the sample firms report asset grants. However, our sample includes 138 financial firms, and only 5 of them report asset grants. When we restrict our analysis to non-financial firms, we find that $43 \%$ (180 out of 421 ) report asset grants. In order to ensure that our tests (in particular of Hypothesis H3) are not affected by the proportion of financial firms in the national samples, we exclude financial firms from here on.

\section{[insert Table 3 about here]}

Table 3 reports on the significance of the international differences. The proportion of firms with asset grants is highest in Germany (89\%) and lowest in Brazil (9\%). The rows ' $\chi^{2 \prime}$ and ' $p$-value', respectively, report $\chi^{2}$ test statistics and the corresponding $p$-values for $\chi^{2}$ tests of independence. The test related to the frequency of asset grants ${ }^{46}$ is significant at the $1 \%$ level.

Table 3 also contains data on other issues which are discussed below: policy choice (Section 6), disclosure quality (Section 7), and the economic importance of grants (Section 8).

\footnotetext{
46 As Table 3 reports, the international difference in frequency for all firms is also significant at the $1 \%$ level.
} 


\section{Policy choice}

\subsection{Univariate analysis}

Table 3 shows that, overall, IAS 20's two options are nearly equally popular: 52\% (94 out of 180) of firms with asset grants chose to present them as deferred income. However, there are obvious international differences: the proportion of firms choosing the deferred income option is highest in Australia and Brazil (100\%) and lowest in Canada (0\%) and South Korea (4\%). Table 3 also reports that the international difference is significant at the $1 \%$ level (see the last line).

The results on policy choice are generally in line with previous research. Based on a sample of 213 German and 224 UK non-financial firms for 2009, Haller and Wehrfritz (2013) found that $52 \%$ of German and $20 \%$ of UK firms received government grants, and that $36 \%$ of German and $82 \%$ of UK firms with grants used the 'deferred income' option under IFRS. In our study, which is based on a very different sample, the respective percentages are $89 \%$ versus $13 \%$ (for receiving grants) and $32 \%$ versus $67 \%$ (for choosing 'deferred income'). These results are in line with the general hypothesis of maintaining pre-IFRS practice when first adopting IFRS. The minority of UK firms which now use the netting approach disclosed no accounting policy when first adopting IFRS or have since changed to that treatment. ${ }^{47}$

47 Out of the three firms which used the 'netting' option in 2013, no policy was disclosed in 2005 by Diageo and Inmarsat. As explained below, BT changed its policy in 2012/13. 
Additionally, as found in previous research on other IFRS policy choices by Nobes and Stadler (2013), Italian and Spanish firms make similar choices. However, our results for Spain are not in line with those of KPMG and von Keitz (2006) who state that $14 \%$ of Spanish firms used the 'deferred income' option in 2005 , whereas we find that $79 \%$ use that option in 2013. This cannot be explained by the four policy changes which occurred in Spain between 2006 and 2013, because two changes were towards and the other two away from the 'deferred income' option. Furthermore, as noted in Section 4.2, the 'deferred income' treatment was required under Spanish national regulations, so would be expected to be the choice under IFRS. Given this, we believe that the information in KPMG and von Keitz (2006) is possibly inaccurate.

We have some specific observations about three countries. The South Korean firms provide a good illustration of our hypothesis, because pre-IFRS local GAAP required netting, and $96 \%$ of the firms chose IAS 20's netting option. At first sight, the Japanese firms do not fit the hypothesis well, in that $75 \%$ of them chose the deferred income approach, which is not available under Japanese GAAP. However, the sample is small. Also, several of the Japanese firms used US GAAP before they adopted IFRS, so Japanese GAAP is not strictly relevant. We comment on pre-IFRS practices of individual Japanese firms in Section 6.3. The results for France are not in line with our predictions. As explained earlier, French GAAP requires a version of the 'deferred income' approach. 
However, 59\% (10 firms) of our French sample use the 'netting' option under IFRS. ${ }^{48}$ In Section 6.3, we investigate whether the pre-IFRS practices of individual firms can shed light on this.

Finally, the last column of Table 3 shows that 12 IFRS policy changes ${ }^{49}$ occurred in the period 2006 to 2013 . In 9 out of 15 countries, no policy change occurred. China had the most changes (5). The changes do not have a clear direction: six are to 'deferred income' and six to 'netting against the asset'. IAS 8 (para. 29) requires a firm to provide an explanation of how the new policy provides information which is reliable and more relevant. We check whether firms explain the policy changes on grants, finding that only two firms do. BT (a UK firm) changed its policy in 2012/13 to the 'netting against asset' option and stated (Annual Report and Form 20-F, p. 107):

Net presentation is considered a more appropriate policy than the previous gross presentation as it better presents the incremental costs to the business.

Guangshen Railway (a Chinese firm) changed its policy in 2010 to 'deferred income' and gave three ${ }^{50}$ reasons (Annual Report 2010, p. 48):

- The practice of other listed companies with similar background;

- Eliminating the difference between the Company's financial statements under IFRS and its PRC statutory financial statements; and

- The change will provide reliable and more relevant information regarding the relevant government grants received by the Company.

48 As required by French GAAP, they all still show 'deferred income' in their parent statements, except that a few show no policy because they are holding companies and have little or no tangible assets.

49 That is, a policy change from one year's IFRS statements of a firm to its next year's IFRS statements.

50 Strictly speaking, the third is not a reason, as IAS 8 (para. 29) requires any policy change to comply with this criterion. 
In summary, the univariate analysis shows a highly significant international difference in policy choice, with little change in policies over seven years. There is some evidence that pre-IFRS regulation influences IFRS practice, which we investigate further in the following two sub-sections.

\subsection{Regression analysis}

Next, we estimate the following logistic regression model in order to analyze the determinants of policy choice:

$$
\begin{aligned}
\text { CHOICEDEF }_{i}= & \alpha+\beta \text { COUNTRYDEF }_{i}+\gamma \text { LEV }_{i}+\theta \text { SIZE }_{i}+\text { industry fixed effects } \\
& +\varepsilon_{i}
\end{aligned}
$$

where i denotes firm; and $\varepsilon$ denotes the regression disturbance term.

CHOICEDEF is a dummy variable with the value ' 1 ' if a firm presents asset grants as deferred income in the balance sheet. COUNTRYDEF is the variable used to test Hypothesis $\mathrm{H} 1$. It is a dummy variable with the value ' 1 ' if a firm is from a country where the deferred income treatment for government grants is or was required or recommended under national GAAP, i.e. Australia, Brazil, China, France, Italy, Russia, Spain, and the UK.

We include several control variables. Since the policy choice affects the size of a firm's liabilities, it affects calculations of leverage based on accounting numbers. Firms with higher leverage may prefer the 'netting' option in order to reduce their reported 
liabilities. We therefore include a variable for leverage. LEV is total debt divided by market capitalization. This definition of leverage is independent of a firm's policy choice and therefore does not result in endogeneity in the regression, because it does not use liabilities or total assets. As further control variables, we include firm SIZE (natural logarithm of market capitalization in US dollars) and industry fixed effects. The latter are dummies for the industries according to the first digit of the ICB code (see Table 2). We do not include grant size as a control variable because only 52 firms made reliable disclosure of this information (shown as ' $v 1$ ' disclosure in Table 3 and explained in the subsequent section), and we would consequently lose more than half of our observations. We do not need to add a variable related to earnings because the policy choice does not affect earnings.

Table 4 shows summary statistics of the variables used in the regression analysis. The number of observations for the regression is the 180 firms with government grants (see Table 3). Since LEV had an extreme observation (LEV of 27.20), we winsorized this variable at the $99^{\text {th }}$ percentile.

[insert Table 4 about here]

Table 5 shows the regression results in terms of marginal effects at means and the corresponding z-statistics (for dummy variables, the marginal effect is for a discrete change of the dummy variable from 0 to 1 ). The first regression in column [I] relates to policy choice. COUNTRYDEF is highly statistically significant, which provides strong support 
for Hypothesis $\mathrm{H} 1$, i.e. the deferred income treatment for government grants is more common in countries where it is or was required or recommended under national GAAP. The variables LEV and SIZE are insignificant. The COUNTRYDEF result is not driven by any particular country: untabulated results show that, when we estimate 15 regressions which each exclude one of the 15 countries, COUNTRYDEF is always statistically significant at the 1\% level; the $z$-statistic is lowest when South Korea is excluded (3.51) and highest when Japan is excluded (7.30).

[insert Table 5 about here]

\subsection{Pre-IFRS policies of individual firms}

Our Hypothesis $\mathrm{H} 1$ is expressed in terms of the effects of pre-IFRS regulations on IFRS policy choice. For countries where these regulations mandated one of IAS 20's options, $\mathrm{H} 1$ also amounts to the more precise hypothesis that an individual firm tends to maintain its pre-IFRS practice. For those other countries whose national GAAPs allowed options, a test of the more precise hypothesis is hampered because full data on pre-IFRS practices cannot be collected for various reasons, as explained at the start of Section 4.2 (including that pre-IFRS disclosure was sometimes poor, and that some of our firms did not exist or were not listed before IFRS was adopted). However, we can to some extent collect evidence, and this is likely to be most relevant when all the following conditions apply to a country: (i) its pre-IFRS regulations allowed the same options as IAS 20, (ii) all firms which adopted IFRS did so at the same time, and (iii) before IFRS became 
compulsory for these firms, they used national GAAP (rather than some using US GAAP, for example). Of our 15 countries, these three conditions apply only for Canada, Hong Kong and South Africa. ${ }^{51}$ However, only nine firms of our sample come from these countries. Of these firms, only three disclosed a policy on asset grants in their annual reports immediately before IFRS adoption. In all cases, as predicted, the policy was maintained under IFRS.

Previous sections have mentioned three other countries for which investigation of the pre-IFRS practices of our sample might be useful: Italy, Japan and France. In Section 4.1, some doubt was expressed about Italy in that its pre-IFRS regulations recommended rather than required the 'deferred income' treatment. By examining pre-IFRS policy choices (in all cases in 2004 reports), we find some evidence to resolve this. Of the 17 Italian firms in our sample, four were not listed in 2004 , six did not provide adequate disclosure, and two chose both options for different grants. Of the remaining five firms with a single clear policy in 2004, all were still using it in 2013 (four deferred income, and one netting).

For Japan, of our nine firms none disclosed a pre-IFRS policy. Thus, for the five countries examined so far, $100 \%$ of firms (for which data is discoverable) maintained preIFRS policies. Although this evidence is reassuring, the difficulties of data collection

51 Even in these three countries, there are a few exceptions. For example, one Canadian firm in our sample used US GAAP before adopting IFRS. The excluded countries are: the seven countries where the 'deferred income' method was required, South Korea where the netting method was required, countries which had different requirements or options from IAS 20 (Brazil, Japan and Switzerland), and countries which adopted IFRS over a long period (Germany, where the first adoptions were in 1994 and the last in 2007, and where some firms used US GAAP before IFRS). 
confirm that testing a more precise version of Hypothesis $\mathrm{H} 1$ (based on the pre-IFRS policies of individual firms) would not be viable.

As mentioned in Section 6.1, the most complicated case is France, for which 10 firms ( $59 \%$ of our sample) use 'netting' in IFRS consolidated statements, although French GAAP required (and requires) 'deferred income', which all the firms still use in their parent statements. Five of these firms $\mathrm{s}^{52}$ apparently had no grants in 2004 , so had to create a new IFRS policy at some point from 2005 onwards. One firm ${ }^{53}$ had already adopted the netting approach under French GAAP by 2004 , but just for consolidated statements; four others ${ }^{54}$ adopted netting for the first time on adoption of IFRS. Particularly for these last four, the French sample does not fit well with the general hypothesis of maintaining previous practices on first-time adoption of IFRS. It is only France which is out-of-line with our predictions. A possible explanation is that French firms have changed their policies to be more in line with the majority practice of their neighbors (Germany and Switzerland), perhaps on an industry basis.

\section{Disclosure quality}

\subsection{Univariate analysis}

Regarding disclosure quality, we are interested in how many firms with asset grants disclose the relevant number (that is, the balance of deferred income or the reduction in

52 Bouygues, Peugeot, Renault, Sanofi-Aventis (now Sanofi) and SUEZ did not disclose a policy on grants in 2004.

53 France Telecom (now Orange).

54 Lafarge, Veolia Environnement and VINCI adopted IFRS in 2005. SUEZ Environnement had its IPO in 2008 and therefore adopted IFRS after 2005. 
asset). Table 3 includes data on disclosure quality. We create two disclosure scores, labeled ' $v 1$ ' and ' $\mathrm{v} 2$ ', where the former is a more demanding measure of disclosure quality. Our scores are based on a detailed assessment of government grant disclosures, as described in Appendix A. Essentially, the ' $v 1$ ' score applies where we are very confident that the number related to asset grants is disclosed. The ' $v 2$ ' score includes all the ' $v 1$ ' firms but also those disclosing a number that probably relates to asset grants but might not be confined to them. Overall, the 'v1' score indicates that $29 \%$ (52 out of 180) of firms disclose the necessary number, whereas the ' $v 2$ ' score shows $46 \%$ (83 out of 180). Again, international differences are apparent, with disclosure quality being best in Spain (ignoring Hong Kong which only has two firms with asset grants). Appendix B shows two examples of best practice: a 'deferred income' example from China and a 'netting' example from Spain. In these examples, the impact of asset grants on both the balance sheet and the income statement is clearly revealed.

Given that we only look for numerical disclosures when a firm states its policy on government grants, we limit the degree to which immateriality explains the lack of disclosures. Although it is possible that some firms' policy notes are 'boiler plate', and that therefore the firms have no numerical information to disclose, we still think that these are examples of poor disclosure because the policy notes are then immaterial information.

Table 3 reports (in its last line) that the international differences in the disclosure scores ' $v 1$ ' and ' $v 2$ ' are both significant at the $10 \%$ level. 


\subsection{Regression analysis}

We estimate the following logistic regression model in order to analyze the determinants of disclosure quality:

$$
\begin{aligned}
\text { DISCLOSURE }_{i}= & \alpha+\beta \text { CHOICEDEF }_{i}+\gamma \text { GRANTFREQ }_{i}+\theta \text { LEV }_{i}+\lambda \text { SIZE }_{i}+ \\
& \text { industry fixed effects }+\varepsilon_{i}
\end{aligned}
$$

where i denotes firm; and $\varepsilon$ denotes the regression disturbance term.

DISCLOSURE is a dummy variable with the value ' 1 ' if a firm discloses the balance sheet-related number about asset grants. We estimate the regression using two alternative variables, DISCLOSURE1 and DISCLOSURE2, which correspond to the disclosure quality scores ' $v 1$ ' and ' $v 2$ ' in Table 3. CHOICEDEF is the variable used to test Hypothesis $\mathrm{H} 2$, and it has already been defined. Hypothesis $\mathrm{H} 3$ is tested using GRANTFREQ, which is the percentage of firms in a firm's country which have received government grants. This variable is the same for each firm in a country and the percentage for each country can be seen in Table 3. The control variables are the same as in the policy choice regression of Section 6 .

Table 5 shows the regression results in terms of marginal effects at means and the corresponding z-statistics. The regression in column [II] uses DISCLOSURE1 as the dependent variable, and that in column [III] uses DISCLOSURE2. CHOICEDEF is positive and statistically significant at the $5 \%$ level in column [II] and at the $1 \%$ level in column [III]. GRANTFREQ is positive and significant at the $5 \%$ level in both columns [II] and [III]. These 
results provide support for Hypotheses $\mathrm{H} 2$ and $\mathrm{H} 3$. Untabulated results show that the level of significance of the variable GRANTFREQ is higher when Brazil and Hong Kong are excluded from the analysis on the grounds that they are only represented by two firms each (significant at the $5 \%$ level and $1 \%$ level using DISCLOSURE1 and DISCLOSURE2 as dependent variables, respectively). The regression in column [II] is overall not statistically significant (see the row ' $p$-value') because LEV, SIZE and the industry fixed effects are not statistically significant. However, when we estimate the regression without the industry fixed effects, CHOICEDEF and GRANTFREQ are still significant at the $5 \%$ level and the regression is now overall significant ( $p$-value $=0.042)$.

\section{The economic importance of asset grants}

In addition to the information already discussed, Table 3 indicates the importance of government grants for firms in the different countries. We discuss this here because our analysis relies on the disclosure scores of Section 7. Table 3 shows the mean of government grants (i.e. the deferred income number or the amount netted against the asset) divided by total shareholders' equity (hereafter 'Grants/Equity') based on firms which have ' $v 1$ ' disclosure quality. This is highest in Italy (14.26\%), where Grants/Equity of the aerospace, defense and security firm Finmeccanica is $104 \%$. There are five further firms (out of the 52 with v1 disclosure) with Grants/Equity above 5\% (untabulated): MTR from Hong Kong (8.28\%), Terna from Italy (5.30\%), and Sacyr Vallehermoso, Ferrovial and Enagas from Spain $(6.64 \%, 8.64 \%$ and $11.9 \%$, respectively). 
In such cases, leverage ratios appear materially higher for those firms choosing the 'deferred income' option, which leaves equity unaffected but increases liabilities. This lack of comparability will affect analysts or researchers who use a database. For example, Worldscope includes 'Deferred Income' under 'Liabilities'.

We have shown that, in over half of the firms (those with neither v1 nor v2 scores; see Table 3), investors and analysts would not have sufficient data to adjust for this problem even if they wanted to. We have doubts about the data for even more firms (those scoring v2 but not v1). For firms for which there might be enough information to adjust ( $47 \%$ of the firms in our case), the literature suggests that users of financial reporting consider note disclosures although they place less weight on them compared to information which is recognized in the financial statements (e.g. Davis-Friday et al., 1999; Hirshleifer and Teoh, 2003; Frederickson et al., 2006; Viger et al., 2008; Clor-Proell et al., 2014).

Overall the average Grants/Equity is $3.50 \%$. Thus, asset grants are important for some firms, though of relatively minor importance for many. ${ }^{55}$ Since our analysis exclusively considers asset grants whereas many firms have grants related to income, the relevance of government grants to firms is considerably larger than our data on Grants/Equity indicate.

\footnotetext{
55 For $65 \%$ of firms which provide disclosure (34 out of 52), Grants/Equity is below $1 \%$ (untabulated).
} 


\section{Summary and conclusions}

Government grants are economically important in some firms, and financial statements can be significantly affected by the related numbers. Despite this, the topic has received little attention from standard-setters or from researchers. The general issue of non-reciprocal transfers is not addressed specifically in the IASB's framework. The main accounting standard on government grants (IAS 20) has, since 1982, offered two options for asset grants (deferred income or deduction from asset) which are both inconsistent with fundamental aspects of the framework. A quite different solution (immediate recognition as income) was proposed for unconditional grants by standard-setters in 1999. This was implemented by the IASB in 2001 for grants relating to certain unusual assets (biological assets under IAS 41) and in 2009 for grants received by unlisted firms which use the special standard designed for them (IFRS for SMES). Yet there are no current proposals to amend IAS 20. The standard-setters have been deterred from resolving the topic of grants because it is related to major conceptual problems, including the scope of liabilities/contingencies and the tension between matching and an asset/liability view.

Our research provides evidence about the frequency and size of grants in 15 countries. We show, for example, that in several countries the majority of firms in our sample receive asset grants, and that they are important for some firms. We also show that IAS 20's two policy options for government grants are roughly equally popular. However, policy choice varies greatly from $100 \%$ treatment as deferred income in Australia to no such treatment in Canada. The choice is highly significantly related to 
country. We hypothesize and find that the deferred income treatment for government grants is more common in countries where it is or was required or recommended under national GAAP. There are few policy changes over time. This is all in line with previous research on other policy topics (e.g. Stadler and Nobes, 2014). To the extent that data on pre-IFRS practices are available, our analysis provides strong support (except in the case of France) for a proposition that a firm's pre-IFRS policy determines its IFRS policy. There is no suggestion in the literature or in any of the policy notes that there are economically different types of asset grant which should lead to different accounting treatments.

IAS 20's disclosure requirements are vague, and many firms do not disclose the balance sheet-related numbers regarding grants. Thus, disclosure practice is not generally sufficient to enable comparable financial statements to be prepared by investors and analysts. Additionally, there are significant international differences, which are detrimental to international comparisons. We hypothesize and find that disclosure (as proxied by one key item: the balance sheet number) is better under the 'deferred income' option and in countries where grants are more common. In some firms (concentrated in particular countries), the numbers relating to government grants have a material effect on ratios such as leverage.

The implications of our discussion and our findings are as follows. IAS 20 is out of line with the IASB's conceptual framework and with more recent standards which address grants for certain types of asset or firm. IAS 20 offers a choice, whereas choices have gradually been removed from other standards. We conclude that government grants 
should be put back on the IASB's agenda. Further, IAS 20's disclosure requirements are rudimentary, leading in some cases to poor practice which does not enable comparability. Revision of these requirements could become an early application of the IASB's (2017) proposals relating to 'Principles of Disclosure'. This document recommends a principlesbased approach to disclosure requirements rather than a detailed listing of them in accounting standards. IAS 20's topics for disclosure (including the 'nature and extent of government grants') might remain suitable, but the proposal (e.g. IASB, 2017, pp. 92-93) is that the principles would be supported by guidance on what this normally entails. On our topic that would include disclosure of the balance of deferred income or the reduction in assets. 


\section{Appendix A}

\section{Disclosure quality scoring}

The following table shows our scoring categories:

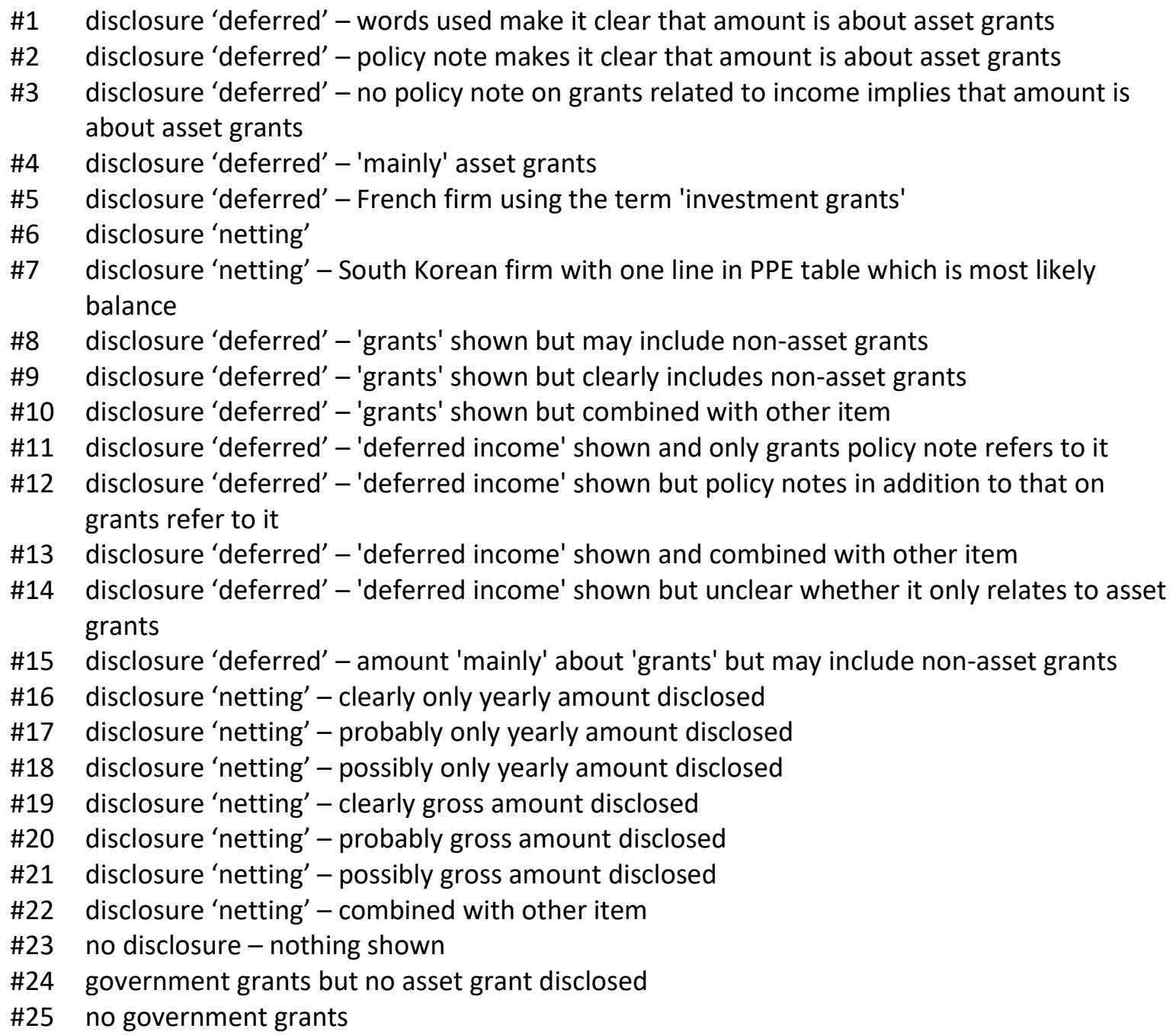

If a firm discloses a number regarding asset grants, our categories account for the following: for firms which use the 'deferred income' option, the disclosed number may include amounts that are not related to asset grants; and for firms which use the 'netting' option, the disclosed number may not be the net balance of asset grants. 
Based on these categories, we create two disclosure scores, ' $v 1$ ' and ' $v 2$ '.

For the ' $v 1$ ' score, we only accept categories \#1 to \#7. For these, we are very confident that the number related to asset grants is disclosed.

For the ' $v 2$ ' score, we accept categories \#1 to \#7 and additionally \#8, \#11, \#15, \#18 and $\# 21$. This measure is a less demanding measure of disclosure quality.

The following table shows the frequencies of the scoring categories for each country:

\begin{tabular}{lcccccccccccccccc}
\hline Score & AU & BR & CA & CH & CN & DE & ES & FR & GB & HK & IT & JP & KR & RU & ZA & TOTAL \\
\hline \#1 & 1 & - & - & - & 4 & 4 & 5 & - & - & - & 5 & 3 & - & 1 & - & 23 \\
$\# 2$ & - & - & - & - & - & 1 & 2 & - & - & - & - & - & - & - & - & 3 \\
$\# 3$ & - & - & - & - & - & - & 1 & 1 & - & - & - & - & - & - & - & 2 \\
$\# 4$ & - & - & - & - & - & 1 & 1 & - & - & - & 1 & - & - & - & 1 & 4 \\
$\# 5$ & - & - & - & - & - & - & - & 2 & - & - & - & - & - & - & - & 2 \\
$\# 6$ & - & - & - & - & - & - & 1 & 1 & 1 & 1 & 2 & - & 4 & - & - & 10 \\
$\# 7$ & - & - & - & - & - & - & - & - & - & - & - & - & 8 & - & - & 8 \\
$\# 8$ & 1 & - & - & - & 10 & - & 2 & 1 & 2 & - & - & 2 & - & - & - & 18 \\
$\# 9$ & - & - & - & - & 1 & - & 2 & - & - & - & - & - & - & - & - & 3 \\
$\# 10$ & - & - & - & - & - & - & 1 & - & 1 & - & 1 & - & - & - & - & 3 \\
$\# 11$ & 1 & - & - & - & 2 & 1 & - & - & - & 1 & - & - & - & - & - & 5 \\
$\# 12$ & - & - & - & - & - & - & - & - & 1 & - & - & - & - & - & - & 1 \\
$\# 13$ & - & - & - & - & 1 & - & - & - & 2 & - & - & - & - & - & - & 3 \\
$\# 14$ & - & - & - & - & 1 & - & - & 1 & - & - & - & - & - & - & - & 2 \\
$\# 15$ & - & - & - & - & 2 & - & - & - & - & - & - & - & - & - & - & 2 \\
$\# 16$ & - & - & - & - & - & 1 & - & 1 & 2 & - & - & - & 2 & - & - & 6 \\
$\# 17$ & - & - & - & - & - & 3 & - & - & - & - & - & - & 1 & 1 & - & 5 \\
$\# 18$ & - & - & - & - & - & 4 & - & - & - & - & - & - & - & - & - & 4 \\
$\# 19$ & - & - & - & - & - & - & - & - & - & - & - & - & - & - & - & 0 \\
$\# 20$ & - & - & - & - & - & 1 & 1 & - & - & - & - & - & 1 & - & - & 3 \\
$\# 21$ & - & - & - & 1 & - & - & 1 & - & - & - & - & - & - & - & - & 2 \\
$\# 22$ & - & - & - & - & - & - & - & - & - & - & - & - & 1 & - & - & 1 \\
$\# 23$ & 2 & 2 & 4 & 4 & 9 & 9 & 2 & 10 & - & - & 8 & 4 & 9 & 5 & 2 & 70 \\
$\# 24$ & 2 & 6 & 2 & - & 2 & 1 & 2 & 2 & 3 & 1 & - & 2 & - & 2 & 2 & 27 \\
$\# 25$ & 22 & 15 & 27 & 7 & 3 & 2 & 2 & 15 & 55 & 11 & 5 & 11 & 7 & 13 & 19 & 214 \\
& & & & & & & & & & & & & & & \\
\hline TOTAL & $\mathbf{2 9}$ & $\mathbf{2 3}$ & $\mathbf{3 3}$ & $\mathbf{1 2}$ & $\mathbf{3 5}$ & $\mathbf{2 8}$ & $\mathbf{2 3}$ & $\mathbf{3 4}$ & $\mathbf{6 7}$ & $\mathbf{1 4}$ & $\mathbf{2 2}$ & $\mathbf{2 2}$ & $\mathbf{3 3}$ & $\mathbf{2 2}$ & $\mathbf{2 4}$ & $\mathbf{4 2 1}$ \\
\hline & & & & & & & & & & & & & & \\
$\#$
\end{tabular}




\section{Appendix B}

\section{Examples of 'best practice' disclosure}

'Deferred income' option (Jiangxi Copper, Annual Report 2013, p. 162):

\begin{tabular}{lcr} 
& 2013 & 2012 \\
& $R M B^{\prime} 000$ & $R M B^{\prime} 000$ \\
& & 277,669 \\
Balance at 1 January & 359,965 & 125,084 \\
Received during the year & 87,060 & $(42,788)$ \\
Recognised in profit or loss & $(37,141)$ & 359,965 \\
\hline Balance at 31 December & 409,884 & \\
\hline \hline & & 332,455 \\
Analysed for reporting purpose as: & & 27,510 \\
\hline $\begin{array}{l}\text { Non-current liabilities } \\
\text { Current liabilities }\end{array}$ & 372,260 & 359,965 \\
\hline
\end{tabular}

The deferred revenue represents government subsidies granted to the Group in relation to its production facilities. It is recognised as deferred income and recognised in profit or loss over the expected useful lives of the facilities. 
'Netting against asset' option (Enagas, Annual Report 2013, pp. 294-295):

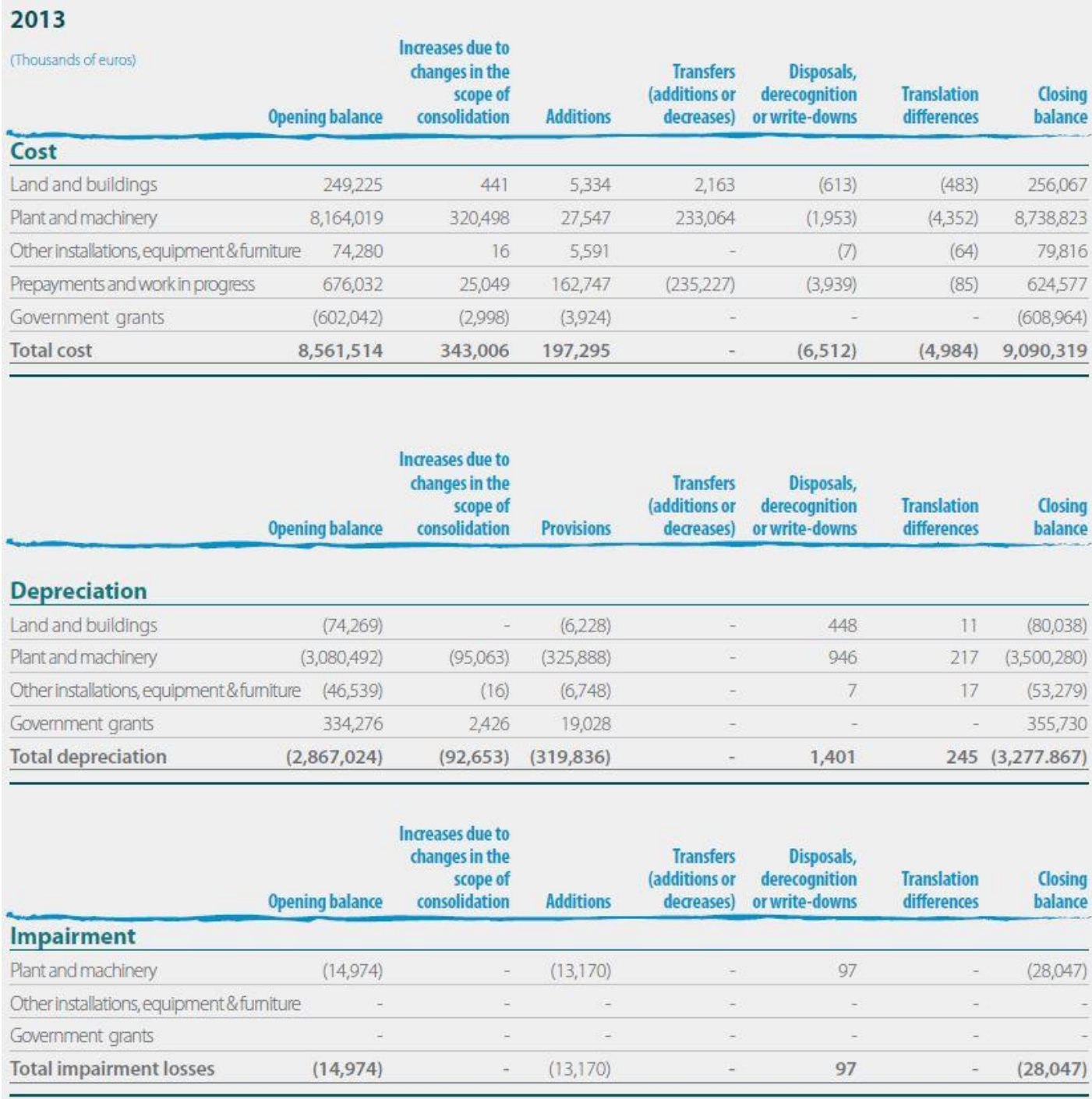

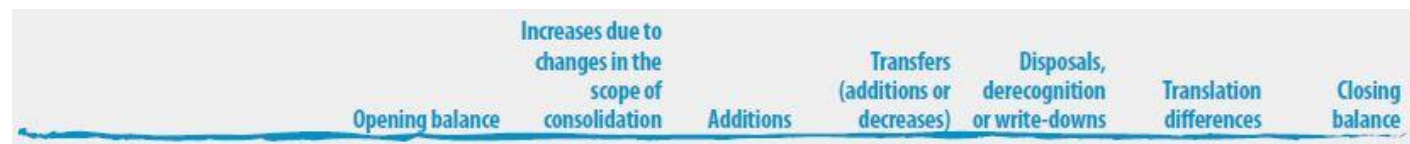

\section{Carrying amount}

\begin{tabular}{|c|c|c|c|c|c|c|c|}
\hline Land and buildings & 174,956 & 441 & (894) & 2,163 & (165) & (472) & 176,029 \\
\hline Plant and machinery & $5,068,553$ & 225,435 & $(311,511)$ & 233,064 & (910) & $(4,135)$ & $5,210,496$ \\
\hline Other installations, equipment \& furniture & 27,741 & - & $(1,157)$ & - & - & (47) & 26,537 \\
\hline Prepayments and work in progress & 676,032 & 25,049 & 162,747 & $(235,227)$ & $(3,939)$ & (85) & 624,577 \\
\hline Governmentgrants & $(267,766)$ & (572) & 15,104 & - & - & - & $(253,234)$ \\
\hline $\begin{array}{l}\text { Total property, } \\
\text { plant and equipment }\end{array}$ & $5,679,516$ & 250,353 & $(135,711)$ & - & $(5,014)$ & $(4,739)$ & $5,784,405$ \\
\hline
\end{tabular}




\section{References}

AAF, 1991. Government Grants. Accounting Advisory Forum, Brussels. http://ec.europa.eu/internal market/accounting/docs/markt-19910312/312 en.pdf (accessed July 3, 2017).

AASB, 2002. The Australian Convergence Handbook. Australian Accounting Standards Board, Melbourne.

Ballwieser, W., 2001. Germany - Individual Accounts, in: Ordelheide, D., KPMG (Eds.), Transnational Accounting. Palgrave, Basingstoke, pp. 1217-1351.

Bertschinger, P., 2001. Switzerland - Individual Accounts, in: Ordelheide, D., KPMG (Eds.), Transnational Accounting. Palgrave, Basingstoke, pp. 2451-2515.

Botosan, C.A., Harris, M.S., 2000. Motivations for a change in disclosure frequency and its consequences: an examination of voluntary quarterly segment disclosures. Journal of Accounting Research 38 (2), 329-353.

Camfferman, K., Zeff, S.A., 2007. Financial Reporting and Global Capital Markets: History of the International Accounting Standards Committee, 1973-2000. Oxford University Press, Oxford.

CFC, 2006. Sumário da Comparação das Prácticas Contábeis Adotadas no Brasil com as Normas Internacionais de Contabilidade - IFRS. Conselho Federal de Contabilidade, Brasilia.

Clor-Proell, S.M., Proell, C.A., Warfielf, T.D., 2014. The effects of presentation salience and measurement subjectivity on nonprofessional investors' fair value judgments, Contemporary Accounting Research, 31 (1), 45-66.

Davis-Friday, P.Y., Folami, L.B., Liu, C.-S., Mittelstaedt, H.F., 1999. The value relevance of financial statement recognition vs. disclosure: evidence from SFAS no. 106. Accounting Review, 74 (4), 403-423.

Diaz, A.L., Torre, P.R., 2001. Spain - Individual Accounts, in: Ordelheide, D., KPMG (Eds.), Transnational Accounting. Palgrave, Basingstoke, pp. 2187-2287.

EFRAG, 2005. Adoption of IFRC 3 Emission Rights. European Financial Reporting Advisory Group, Brussels. http://ec.europa.eu/internal market/accounting/docs/ias/efrag/efrag-2005-05endorsement-letter en.pdf (accessed March 21, 2016).

EFRAG, 2016. Proactive - Transactions with Governments. European Financial Reporting Advisory Group, Brussels. http://www.efrag.org/Activities/1603140821453221/Proactive---Transactions-withGovernments (accessed 8.24.2016).

Ernst \& Young, 2005. IFRS/US GAAP Comparison. Lexis Nexis, London. 
EY, 2017. China Accounting Alert (June 2017). EY, Beijing.

http://www.ey.com/Publication/vwLUAssets/ey-china-accounting-alert-june-2017en/\$FFILE/ey-china-accounting-alert-june-2017-en.pdf (accessed 1.11.2018).

FASB, 1980. Statement of Financial Accounting Concepts, No. 3. Financial Accounting Standards Board, Norwalk, CT.

FASB, 1985. Statement of Financial Accounting Concepts, No. 6. Financial Accounting Standards Board, Norwalk, CT.

FEE, 1991. European Survey of Published Accounts 1991. Fédération des Experts Comptables Européens, Brussels.

Frederickson, J.R., Hodge, F.D., Pratt, J.H., 2006. The evolution of stock option accounting: Disclosure, voluntary recognition, mandated recognition, and management disavowals. Accounting Review 81 (5), 1073-1093.

Gélard, G., 2001. France - Individual Accounts, in: Ordelheide, D., KPMG (Eds.), Transnational Accounting. Palgrave, Basingstoke, 1009-1127.

Gonzalo, J.A., Gallizo, J.L., 1992. European Financial Reporting - Spain. Routledge, London.

Haller, A., Wehrfritz, M., 2013. The impact of national GAAP and accounting traditions on IFRS policy selection: evidence from Germany and the UK. Journal of International Accounting, Auditing and Taxation 22 (1), 39-56.

Hirshleifer, D., Teoh, S.H., 2003. Limited attention, information disclosure, and financial reporting. Journal of Accounting and Economics 36 (1-3), 337-386.

IASB, 2004. Update, February. International Accounting Standards Board, London.

IASB, 2010a. The Conceptual Framework for Financial Reporting. International Accounting Standards Board, London.

IASB, 2010b. Project Update: Amendments to IAS 20 (July 2010). International Accounting Standards Board, London.

IASB, 2013. A Review of the Conceptual Framework for Financial Reporting. International Accounting Standards Board, London.

IASB, 2015a. Request for Views: 2015 Agenda Consultation. International Accounting Standards Board, London.

IASB, 2015b. Pollutant Pricing Mechanisms, Agenda Paper 6, of Board Meeting of October 2015. International Accounting Standards Board, London. http://www.ifrs.org/Meetings/MeetingDocs/IASB/2015/October/AP06-PPM.pdf (accessed March 21, 2016).

IASB, 2017. Disclosure Initiative - Principles of Disclosure. Discussion Paper DP/2017/1. International Accounting Standards Board, London. 
IASC, 1989. Framework for the Preparation and Presentation of Financial Statements. International Accounting Standards Committee, London.

KPMG, von Keitz, I., 2006. The Application of IFRS: Choices in Practice. KPMG, London.

Kvaal, E., Nobes, C.W., 2010. International differences in IFRS policy choice: a research note. Accounting and Business Research 40 (2), 173-187.

Kvaal, E., Nobes, C.W., 2012. IFRS policy changes and the continuation of national patterns of IFRS practice. European Accounting Review 21 (2), 343-371.

Lourenço, I., Sarquis, R., Castelo Branco, M., Pais, C., 2015. Extending the classification of European countries by their IFRS practices: a research note. Accounting in Europe 12 (1), 223-232.

Meek, G.K., Roberts, C.B., Gray, S.J., 1995. Factors influencing voluntary annual report disclosures by U.S., U.K. and continental European multinational corporations. Journal of International Business Studies 26 (3), 555-572.

Morley, J., 2016. Internal lobbying at the IASB. Journal of Accounting and Public Policy 35 (3), 224-255.

Nobes, C.W., 1983. The evolution of the harmonising provisions of the 1980 and 1981 Companies Acts. Accounting and Business Research 14 (53), 43-53.

Nobes, C.W., 2006. The survival of international differences under IFRS: towards a research agenda. Accounting and Business Research 36 (3), 233-245.

Nobes, C.W., 2011. IFRS practices and the persistence of accounting system classification. Abacus 47 (3), 267-283.

Nobes, C.W., Stadler, C., 2013. How arbitrary are international accounting classifications? Lessons from centuries of classifying in many disciplines, and experiments with IFRS data. Accounting, Organizations and Society 38 (8), 573-595.

OECD, 2015. Country-by-Country Reporting Implementation Package. Organisation for Economic Cooperation and Development, Paris. https://www.oecd.org/ctp/transferpricing/beps-action-13-country-by-country-reporting-implementation-package.pdf (accessed August 12, 2016).

Ordelheide, D., Pfaff, D., 1994. European Financial Reporting: Germany. Routledge, London.

PwC, 2013. Similarities and Differences: A Comparison of IFRS and JP GAAP. PricewaterhouseCoopers, Tokyo.

Sprouse, R.T., 1978. The importance of earnings in the conceptual framework. Journal of Accountancy 145 (1), January, 64-71.

Stadler, C., Nobes, C.W., 2014. The influence of country, industry, and topic factors on IFRS policy choice. Abacus 50 (4), 386-421. 
Street, D.L., 2005. Inside G4+1: The Working Group's Role in the Evolution of the International Accounting Standard Setting Process. Institute of Chartered Accountants in England and Wales, London.

Viger, C., Belzile, R., Anandarajan, A.A., 2008. Disclosure versus recognition of stock option compensation: Effect on the credit decisions of loan officers. Behavioral Research in Accounting 20 (1), 93-113.

Westwood, M., Mackenzie, A., 1999. Accounting by Recipients for Non-reciprocal Transfers, excluding Contributions by Owners. Financial Accounting Standards Board for G4+1, Norwalk, CT.

Zambon, S., 1998. Italy, in D. Alexander and D. Archer. European Accounting Guide, Harcourt Brace, Orlando, FL, pp. 523-669.

Zeff, S.A., 2016a. The Trueblood Study Group on the Objectives of Financial Statements (1971-73): A historical study. Journal of Accounting and Public Policy 35 (2), 134161.

Zeff, S.A., 2016b. Political lobbying on accounting standards - US, UK and international experience, in: Nobes, C.W., Parker, R.H. (Eds.), Comparative International Accounting. Pearson, Harlow, pp. 267-299. 
Table 1 Sample selection.

\begin{tabular}{|c|c|c|c|c|c|c|c|c|c|c|c|c|c|c|c|c|}
\hline Country & AU & BR & CA & $\mathrm{CH}$ & $\mathrm{CN}$ & $\mathrm{DE}$ & ES & FR & GB & HK & IT & JP & KR & $\mathbf{R U}$ & ZA & TOTAL \\
\hline Index constituents on $31 / 12 / 2005$ & 50 & & & 26 & 40 & 40 & 35 & 40 & 100 & 33 & 40 & & & & 40 & \\
\hline Index constituents on $31 / 12 / 2010$ & 50 & 50 & 60 & 20 & 40 & 40 & 35 & 40 & 100 & 45 & 40 & & 50 & 50 & 40 & \\
\hline Unique firms per country & 64 & 48 & 60 & 29 & 58 & 49 & 45 & 47 & 131 & 51 & 52 & 29 & 50 & 48 & 52 & 813 \\
\hline \multicolumn{17}{|l|}{ Excluded: } \\
\hline - Foreign firms & 4 & - & - & - & - & 1 & 2 & 5 & 1 & 13 & 2 & - & - & - & 8 & 36 \\
\hline - Subsidiaries of listed foreign firms & 2 & 7 & 1 & - & - & 3 & 2 & 1 & 5 & 4 & 3 & 1 & - & 1 & 7 & 37 \\
\hline - HK firms with CN ultimate parent & - & - & - & - & - & - & - & - & - & 10 & - & - & - & - & - & 10 \\
\hline - Firms with other foreign influence & 3 & - & - & - & - & - & - & - & 10 & - & - & - & - & - & 2 & 15 \\
\hline - Subsidiaries of listed domestic firms & - & 2 & 1 & - & 3 & 3 & 4 & - & - & 1 & 5 & 1 & 1 & 8 & 2 & 31 \\
\hline - No IFRS data for 2013 (US GAAP or local GAAP) & - & - & 11 & 9 & 7 & 1 & - & - & 1 & - & - & - & - & 6 & - & 35 \\
\hline - No data for 2013 & 8 & 4 & 2 & 1 & - & 3 & 6 & 1 & 24 & 1 & 4 & 2 & 7 & 7 & 4 & 74 \\
\hline - Data on asset grants unclear & - & 1 & 1 & 1 & 1 & 3 & - & - & 1 & - & 4 & - & 1 & 1 & - & 14 \\
\hline - Data on asset grants immaterial & - & - & 1 & - & - & 1 & - & - & - & - & - & - & - & - & - & 2 \\
\hline Firms for analysis & 47 & 34 & 43 & 18 & 47 & 34 & 31 & 40 & 89 & 22 & 34 & 25 & 41 & 25 & 29 & 559 \\
\hline
\end{tabular}

This table shows the sample selection per country. The countries are Australia (AU), Brazil (BR), Canada (CA), Switzerland (CH), China (CN), Germany (DE), Spain (ES), France (FR), United Kingdom (GB), Hong Kong (HK), Italy (IT), Japan (JP), South Korea (KR), Russia (RU) and South Africa (ZA). Except for Japan, the sample comprises the constituents of the major stock market index of the respective country: S\&P/ASX-50 (AU), IBrX-50 (BR), S\&P/TSX-60 (CA), SMI (CH), Hang Seng China Enterprises Index (CN), DAX-30 \& 10 largest (by market capitalization) constituents of MDAX-50 (DE), IBEX-35 (ES), CAC-40 (FR), FTSE-100 (GB), Hang Seng (HK), (S\&P/MIB-40) FTSE/MIB-40 (IT), KOSPI-50 (KR), RTS-50 (RU) and FTSE/JSE Top 40 (ZA). For most countries, the sample comprises the constituents of the index on 31 December 2005 or 31 December 2010 or both. For Canada, Russia and South Korea, the sample comprises the constituents on 31 December 2010; and for Brazil, those on 30 June 2012 . There are only 48 unique firms for Brazil and for Russia because, in both cases, their indices include two types of shares for two firms. For Japan, the sample comprises those firms which had chosen to use IFRS by 2013. Details and examples related to the first five exclusion criteria are as follows: foreign firms (e.g. Telecom New Zealand in AU); subsidiaries of listed foreign firms (e.g. TUI Travel in GB, which is a subsidiary of TUI in DE); HK firms with CN ultimate parent which is a Chinese state-owned enterprise (e.g. China Mobile); firms with other foreign influence, meaning those with a dual-listed companies structure (e.g. BHP Billiton in AU and GB) or a headquarters abroad (e.g. Royal Dutch Shell in 
GB, which has its headquarters in the Netherlands); and subsidiaries of listed domestic firms already included in the sample (e.g. IBERDROLA RENOVABLES in ES, which is a subsidiary of IBERDROLA). Data on index constituents are from the respective stock exchanges or index providers, and the remaining data (including ownership data) are hand-collected. 
Table 2 Sample by country and industry.

\begin{tabular}{|c|c|c|c|c|c|c|c|c|c|c|c|c|c|c|c|c|}
\hline & $\mathrm{AU}$ & BR & CA & $\mathrm{CH}$ & $\mathrm{CN}$ & $\mathrm{DE}$ & ES & FR & GB & HK & IT & JP & KR & RU & ZA & TOTAL \\
\hline INDUSTRYO: Oil \& gas & 3 & 1 & 8 & 0 & 4 & 0 & 4 & 2 & 6 & 0 & 1 & 0 & 4 & 6 & 1 & 40 \\
\hline INDUSTRY1: Basic materials & 6 & 7 & 11 & 3 & 5 & 6 & 1 & 1 & 5 & 0 & 0 & 0 & 4 & 7 & 7 & 63 \\
\hline INDUSTRY2: Industrials & 7 & 2 & 2 & 2 & 11 & 6 & 7 & 8 & 15 & 4 & 5 & 10 & 8 & 2 & 5 & 94 \\
\hline INDUSTRY3: Consumer goods & 1 & 7 & 1 & 2 & 4 & 7 & 1 & 7 & 9 & 3 & 6 & 2 & 6 & 1 & 2 & 59 \\
\hline INDUSTRY4: Health care & 2 & 1 & 0 & 3 & 1 & 2 & 1 & 2 & 3 & 0 & 1 & 3 & 0 & 1 & 2 & 22 \\
\hline INDUSTRY5: Consumer services & 7 & 3 & 7 & 0 & 4 & 4 & 3 & 7 & 18 & 3 & 5 & 4 & 4 & 2 & 5 & 76 \\
\hline INDUSTRY6: Telecommunications & 1 & 1 & 3 & 1 & 1 & 1 & 1 & 1 & 4 & 1 & 1 & 1 & 2 & 0 & 2 & 21 \\
\hline INDUSTRY7: Utilities & 2 & 1 & 1 & 0 & 3 & 2 & 4 & 4 & 5 & 3 & 3 & 0 & 2 & 3 & 0 & 33 \\
\hline INDUSTRY8: Financials & 18 & 11 & 10 & 6 & 12 & 6 & 8 & 6 & 22 & 8 & 12 & 3 & 8 & 3 & 5 & 138 \\
\hline INDUSTRY9: Technology & 0 & 0 & 0 & 1 & 2 & 0 & 1 & 2 & 2 & 0 & 0 & 2 & 3 & 0 & 0 & 13 \\
\hline$\overline{\text { TOTAL }}$ & 47 & 34 & 43 & 18 & 47 & 34 & 31 & 40 & 89 & 22 & 34 & 25 & 41 & 25 & 29 & 559 \\
\hline
\end{tabular}

This table reports the country and industry distribution of the sample firms. The countries are Australia (AU), Brazil (BR), Canada (CA), Switzerland (CH), China (CN), Germany (DE), Spain (ES), France (FR), United Kingdom (GB), Hong Kong (HK), Italy (IT), Japan, (JP), South Korea (KR), Russia (RU), and South Africa (ZA). Industry is according to the first digit of the Industry Classification Benchmark (ICB) code (Worldscope code: WC07040). 
Table 3 Frequencies of government grants, policy choice and disclosure quality.

\begin{tabular}{|c|c|c|c|c|c|c|c|c|c|c|c|c|c|c|c|}
\hline \multirow{2}{*}{\multicolumn{2}{|c|}{ Country }} & \multicolumn{3}{|c|}{ All Firms } & \multicolumn{11}{|c|}{ Non-financial Firms } \\
\hline & & \multirow{2}{*}{$\begin{array}{c}\text { Firms } \\
47\end{array}$} & \multicolumn{2}{|c|}{$\begin{array}{c}\text { Government } \\
\text { Grants }\end{array}$} & \multirow{2}{*}{$\begin{array}{c}\text { Firms } \\
29\end{array}$} & \multicolumn{2}{|c|}{$\begin{array}{l}\text { Government } \\
\text { Grants }\end{array}$} & \multicolumn{2}{|c|}{$\begin{array}{c}\text { Policy: } \\
\text { Deferred Income } \\
\end{array}$} & \multicolumn{2}{|c|}{$\begin{array}{l}\text { Disclosure: } \\
\text { Numbers v1 }\end{array}$} & \multicolumn{2}{|c|}{$\begin{array}{l}\text { Disclosure: } \\
\text { Numbers v2 }\end{array}$} & \multirow{2}{*}{$\begin{array}{c}\text { Grants/Equity } \\
2.50 \%\end{array}$} & \multirow{2}{*}{$\begin{array}{c}\text { Policy: } \\
\text { Changes } \\
0\end{array}$} \\
\hline$A U$ & Australia & & 6 & $13 \%$ & & 5 & $17 \%$ & 5 & $100 \%$ & 1 & $20 \%$ & 3 & $60 \%$ & & \\
\hline $\mathrm{BR}$ & Brazil & 34 & 2 & $6 \%$ & 23 & 2 & $9 \%$ & 2 & $100 \%$ & 0 & $0 \%$ & 0 & $0 \%$ & NA & 0 \\
\hline CA & Canada & 43 & 4 & $9 \%$ & 33 & 4 & $12 \%$ & 0 & $0 \%$ & 0 & $0 \%$ & 0 & $0 \%$ & NA & 0 \\
\hline $\mathrm{CH}$ & Switzerland & 18 & 5 & $28 \%$ & 12 & 5 & $42 \%$ & 2 & $40 \%$ & 0 & $0 \%$ & 1 & $20 \%$ & NA & 0 \\
\hline $\mathrm{CN}$ & China & 47 & 31 & $66 \%$ & 35 & 30 & $86 \%$ & 25 & $83 \%$ & 4 & $13 \%$ & 18 & $60 \%$ & $0.38 \%$ & 5 \\
\hline$D E$ & Germany & 34 & 25 & $74 \%$ & 28 & 25 & $89 \%$ & 8 & $32 \%$ & 6 & $24 \%$ & 11 & $44 \%$ & $1.07 \%$ & 1 \\
\hline ES & Spain & 31 & 19 & $61 \%$ & 23 & 19 & $83 \%$ & 15 & $79 \%$ & 10 & $53 \%$ & 13 & $68 \%$ & $3.39 \%$ & 4 \\
\hline FR & France & 40 & 18 & $45 \%$ & 34 & 17 & $50 \%$ & 7 & $41 \%$ & 4 & $24 \%$ & 5 & $29 \%$ & $0.43 \%$ & 0 \\
\hline GB & United Kingdom & 89 & 9 & $10 \%$ & 67 & 9 & $13 \%$ & 6 & $67 \%$ & 1 & $11 \%$ & 3 & $33 \%$ & $1.58 \%$ & 1 \\
\hline HK & Hong Kong & 22 & 2 & $9 \%$ & 14 & 2 & $14 \%$ & 1 & $50 \%$ & 1 & $50 \%$ & 2 & $100 \%$ & $8.28 \%$ & 0 \\
\hline IT & Italy & 34 & 18 & $53 \%$ & 22 & 17 & $77 \%$ & 12 & $71 \%$ & 8 & $47 \%$ & 8 & $47 \%$ & $14.26 \%$ & 0 \\
\hline$J P$ & Japan & 25 & 9 & $36 \%$ & 22 & 9 & $41 \%$ & 6 & $67 \%$ & 3 & $33 \%$ & 5 & $56 \%$ & $1.95 \%$ & 0 \\
\hline KR & South Korea & 41 & 27 & $66 \%$ & 33 & 26 & $79 \%$ & 1 & $4 \%$ & 12 & $46 \%$ & 12 & $46 \%$ & $0.43 \%$ & 1 \\
\hline RU & Russia & 25 & 7 & $28 \%$ & 22 & 7 & $32 \%$ & 3 & $43 \%$ & 1 & $14 \%$ & 1 & $14 \%$ & $0.50 \%$ & 0 \\
\hline ZA & South Africa & 29 & 3 & $10 \%$ & 24 & 3 & $13 \%$ & 1 & $33 \%$ & 1 & $33 \%$ & 1 & $33 \%$ & $0.28 \%$ & 0 \\
\hline \multicolumn{2}{|c|}{ TOTAL } & 559 & 185 & $33 \%$ & 421 & 180 & $43 \%$ & 94 & $52 \%$ & 52 & $29 \%$ & 83 & $46 \%$ & $3.50 \%$ & 12 \\
\hline \multicolumn{2}{|c|}{$\chi^{2}$} & & & 153.13 & & & 164.56 & & 61.95 & & 23.10 & & 21.29 & & \\
\hline \multicolumn{2}{|c|}{$\hat{p}$ value } & & & 0.000 & & & 0.000 & & 0.000 & & 0.059 & & 0.094 & & \\
\hline
\end{tabular}

This table shows frequency counts of government grants, policy choice and disclosure quality in 2013. The columns 'Firms' show the total numbers of firms analyzed by country. This information is shown for 'All Firms' and for the sub-sample of 'Non-financial Firms'. The same applies to the columns 'Government Grants', which show the numbers and percentages of firms with asset grants. The column 'Policy: Deferred Income' shows the number and percentage of firms which present government grants relating to assets as deferred income in the balance sheet (the alternative option is to net the grant against the asset). The columns 'Disclosure: Numbers v1' and 
'Disclosure: Numbers v2' show the numbers and percentages of firms which disclose balance sheet-related numbers regarding asset grants. The former is a more demanding measure of disclosure quality (see Appendix A). The column 'Grants/Equity' shows the mean of asset grants divided by total shareholders' equity and is based on the firms which satisfy 'Disclosure: Numbers v1'. The column 'Policy: Changes' shows the total number of changes of the government grant policy choice in the period 2006 to 2013. ' $\chi^{2 \text { ' }}$ and ' $p$-value' report the $\chi^{2}$ test statistic and the corresponding $p$-value for $\chi^{2}$ tests of independence, respectively. Data on government grants are handcollected and the remaining data are from Worldscope. The Worldscope code used is WC03995 for Grants/Equity. 
Table 4 Summary statistics.

\begin{tabular}{lrrrrrrrr}
\hline Variable & N & Mean & StdDev & Min & Q1 & Median & Q3 & Max \\
\hline CHOICEDEF & 180 & 0.522 & 0.501 & & & & & \\
DISCLOSURE1 & 180 & 0.289 & 0.455 & & & & & \\
DISCLOSURE2 & 180 & 0.461 & 0.500 & & & & & \\
& & & & & & & & \\
COUNTRYDEF & 180 & 0.589 & 0.493 & & & & & \\
GRANTFREQ & 180 & 0.651 & 0.266 & 0.087 & 0.417 & 0.788 & 0.857 & 0.893 \\
LEV & 180 & 1.164 & 1.616 & 0.004 & 0.232 & 0.592 & 1.220 & 9.695 \\
SIZE & 180 & 16.171 & 1.351 & 10.533 & 15.344 & 16.079 & 17.067 & 19.268 \\
& & & & & & & & \\
\hline
\end{tabular}

This table reports summary statistics for the variables used to analyze the determinants of policy choice and disclosure quality regarding government grants for non-financial firms in 2013: mean (percentage for dummy variables), standard deviation (StdDev), minimum (Min), first quartile (Q1), median, third quartile (Q3) and maximum (Max). $\mathrm{N}$ is the number of observations/firms. The variables are CHOICEDEF (a dummy variable with the value ' 1 ' if a firm presents government grants relating to assets as deferred income in the balance sheet), DISCLOSURE1 and DISCLOSURE2 (dummy variables with the value ' 1 ' if a firm discloses the balance sheet-related number regarding asset grants, where the former is a more demanding measure of disclosure quality, see Appendix A), COUNTRYDEF (a dummy variable with the value ' 1 ' if a firm is from a country where the deferred income treatment for government grants is or was required or recommended under national GAAP, i.e. Australia, Brazil, China, France, Italy, Russia, Spain, and the UK), GRANTFREQ (percentage of firms in a firm's country which have received government grants), LEV (total debt divided by market capitalization), and SIZE (natural logarithm of market capitalization in US dollars). Data on government grants are hand-collected and the remaining data are from Worldscope. The Worldscope codes used are WC03255/WC08001 for LEV and WC07210 for SIZE. 
Table 5 Determinants of policy choice and disclosure quality.

\begin{tabular}{|c|c|c|c|c|}
\hline & Hypothesis & [I] & [II] & [III] \\
\hline Dependent variable & & CHOICEDEF & DISCLOSURE1 & DISCLOSURE2 \\
\hline COUNTRYDEF & $\mathrm{H} 1$ & $\begin{array}{c}0.452^{* * *} \\
(6.30)\end{array}$ & & \\
\hline CHOICEDEF & $\mathrm{H} 2$ & & $\begin{array}{c}0.157^{* *} \\
(2.26)\end{array}$ & $\begin{array}{c}0.377^{* * *} \\
(5.00)\end{array}$ \\
\hline GRANTFREQ & H3 & & $\begin{array}{c}0.286 * * \\
(2.03)\end{array}$ & $\begin{array}{c}0.404^{* *} \\
(2.39)\end{array}$ \\
\hline LEV & & $\begin{array}{l}-0.037 \\
(-1.27)\end{array}$ & $\begin{array}{l}-0.037 \\
(-1.34)\end{array}$ & $\begin{array}{l}-0.005 \\
(-0.20)\end{array}$ \\
\hline SIZE & & $\begin{array}{l}-0.065 \\
(-1.53)\end{array}$ & $\begin{array}{l}0.006 \\
(0.22)\end{array}$ & $\begin{array}{l}0.045 \\
(1.16)\end{array}$ \\
\hline Industry fixed effects & & Yes & Yes & Yes \\
\hline$p$-value & & 0.000 & 0.521 & 0.001 \\
\hline Pseudo $\mathrm{R}^{2}$ & & 0.178 & 0.054 & 0.168 \\
\hline$\%$ classified correctly & & $72.22 \%$ & $69.44 \%$ & $70.56 \%$ \\
\hline Observations/firms & & 180 & 180 & 180 \\
\hline
\end{tabular}

This table reports the results of Logit regressions analyzing the determinants of policy choice and disclosure quality regarding government grants for non-financial firms in 2013. The results are marginal effects at means and (in parentheses) the corresponding $z$-statistics (for dummy variables, the marginal effect is for a discrete change of the dummy variable from 0 to 1 ). The variables are defined in Table 4 . The industry fixed effects are according to the first digit of the ICB code (see Table 2). The results are based on heteroscedasticity-robust standard errors. ${ }^{*}, * *$ and ${ }^{* * *}$ indicate significance at the $10 \%, 5 \%$ and $1 \%$ level, respectively (two-sided). 